\title{
Jewish National Custom and Its Religious Origin
}

\author{
Xiumiao Wang \\ Zaozhuang University, Zaozhuang, Shandong, 277160
}

Keywords: Jewish People; Life Custom; Judaism; Diet

\begin{abstract}
The Jewish nation is a wonderful work in the world's national forest, and the strange folk customs make the Jewish nation dazzling. To explore the Jewish national life customs, found its customs and ethnic-religious beliefs - Judaism has a very deep contact. According to the Jewish classic "Hebrew Bible", lists what is clean food, which is unclean food and other food taboos, clothing and religious education and other living customs.
\end{abstract}

\section{Introduction}

The Jewish people in the world of national forest is a wonderful work, strange clothing, food, education and other aspects of life to show the living customs of the Jewish nation dazzling. Exploring the Jewish people's living customs, discovering their customs and ethnic religious beliefs - Judaism has deep ties. Returning to the ancestors of the Jewish nation to Abraham, a messenger of God showed him, and gave him the land of Canaan, and gave to his descendants the law of God, "the Moses", which is the origin of the faith of Judaism. Jacob was the grandson of Abraham, and later renamed Israel, and gave twelve sons to become the twelve tribes of Israel, and Judah was one of the tribes, but most of the tribe were later taken captive, and only the tribe of Judah The weak tribe of the tribe of Benjamin, and the Levites of the priesthood of the priesthood, were all together, and they were the ancestors of the Jews today. "Judas" and "Jewish" in Hebrew is a word YEHUDA, the Chinese translation of the general said the nation, translated as Jewish; said the place name translated as "Ye Hu Da", said the name translated as "Judah" [1]. The Jewish nation, in the course of two thousand years of great flow, still showed a strong national character and maintained a unique culture of its own nation, which had a very close relationship with their national beliefs.

\section{Food Taboo}

The plants are clean and eaten, but the Hebrew Bible and the Hebrew Bible, Deuteronomy, divides the animals into clean and unclean, and the Jews are absolutely unavoidable unclean animal.

All the birds can eat, cattle, sheep, deer and other cloven hoofs at the same time ruminant mammals for the clean animals, you can eat. Judaism stipulates that the blood of an animal can not be eaten, because the blood has life, so that the eyes of the LORD God are positive, and the Jews can be blessed. Slaughtering animals must be a specially trained, practicing card slaughter division, using a specific method of slaughter, knife killed, so that the blood of animals can quickly flow net, slaughter when the slaughter of the inspectors supervision, qualified to Place the meat in the cold water and add salt to remove the remaining blood from the meat, and finally by the slaughter inspector pack, paste the clean food logo for sale. Some special devout Jews to ensure that the food is clean, eat only Rabbi Rabbi test, and produced by the canned cattle, mutton [2]. Unclean animals such as pigs, rabbits, horses, camels and other edible, due to old, sick and abnormal death of cattle, sheep, poultry is also unclean, can not eat. Where animals, eels, shrimp, lobster, clams and other non-fins, no scales, no bones, shellfish, are also considered unclean animals in the water, land or air, and can not be eaten. Hebrew "The Bible" also provides for not to eat raw meat, not allowed to eat beef and milk at the same time; not allowed to eat cattle, sheep subcutaneous animal fat; cattle, sheep tendons can not eat, this is because the Hebrew " Genesis recorded in the Jewish ancestors of Jesus, the cry of the angels of God, blessed him with the angels wrestling all night, and at dawn he 
found that hamstring was injured, for which the Jews did not eat animal hamstring, The angel touched the bars of Jacob's thighs.

\section{Clothing}

Due to the large temperature difference between day and night in the Palestinian area, the traditional costumes of the Jewish people are robes, cloaks, hats and scarves. Robe in the hot sun can sunscreen, cold night struck, tight gown, you can keep warm. If the Jewish poverty is the only piece of clothing, and when the sun goes down, be sure to give it back to him, so that he can cover the clothes and sleep, so that blessings can be called before God.

The robe is often marked with spears to commemorate the law of the Lord by Moses, and the ear is wrapped with eight wool yarns, and the knot is divided into six knots: "You commanded the children of Israel to call their children and grandchildren And he made a spike on the edge of his clothes, and nailed a blue ribbon on the bottom edge of the ear, and remembered the law of the LORD God all [2].

The traditional Jews go out to the belt, the belt is a very important part of their wear, the rich use it to send a knife, a sword; traveler or grazing people, then must bring things on the belt: dry food, Water bag, animal husbandry and other whip. Bundle on the belt, is conducive to work, so the waist is also a symbol of strength, "God is both powerful waist, so the power to make the mountain stability [2]." Hood is usually a square cloth diagonal , With linen woven, thick texture. Jewish women also wear veil, in addition to the role of shade, but also said the meaning of humility. But this custom is as strict as the Arabs in the Jewish, especially the working class of women, do not wear a veil when working, unmarried girls pay more attention to the veil than married women [3].

Jews are forbidden to wear men's and women's dresses, women can not wear men's clothing, men can not wear women's clothing, because doing so is the Lord God hate. For clothing, the Jews are prohibited from wearing clothing made of wool and fine linen blended, "can not wear wool, fine linen mixed stuffing clothes [4]." But for cotton and fine linen, silk and wool blended clothing are Not forbidden.

Take off the shoes that off the filth, so enter the family and religious holy places should take off the shoes. When Joshua saw Jehovah, the Lord commanded him to take the shoes off, because his place was holy [2].

However, after more than 2,000 years of exotic life, the Jewish dress is affected by the original country of residence, the Jewish clothing is extremely diverse, both traditional robes, and modern suits and ties. In the hot summer months of Jerusalem or Tel Aviv, bare arms, young men and women, and strolling through the streets, often with their white shirts, black robes, black hats Orthodox factions; in very formal banquets or other social occasions, some people suits and fits, pay attention to Europe and the United States of the brand name and fashion, some people still identify the difference between the traditional clothing denomination as a symbol of status and status [5].

\section{Religious Education}

In addition to the top thinkers of Marx, Einstein, Freud, in the field of philosophy, science, literature, art, and economy, politics, in the fields of the Jewish people, Pioneers and pilot of the crowd, can be found in Jewish scholars. Almost every year the Nobel Prize has a Jewish award. The great achievement of the Jews was inseparable from their education. The most characteristic of the Jewish people is the education of religion. The importance of religious education in the Jewish people can be compared with life, even in the loss of their homes, away from the wilderness of the days of the horizon, the Jewish people have not forgotten to teach the next generation of Judaism knowledge and law, which is the Jewish people still maintain its The basic factors of national character.

There are two main books in Judaism: the first and most important work is the Hebrew Bible (also known as "Tarnach"), the second is "Talmud", it is " "And the" 613 commandments "in the 
Jewish scriptures. "Tarim" a total of 20 volumes of more than 1200 pages, more than 250 million words, including "Mississauga", "leather horse" and "Midra West" three parts, "Talmud" wrote 10 centuries, A total of more than 2,000 Jewish scholars involved in the preparation, is the Jewish history of their own national culture thinking. "The Bible" and "Talmud" constitute the cornerstone of Judaism [6].

The Jewish religious education was first carried out in the family. Since childhood, the Jewish parents began to religious influence on the children, so that children learn from the Hebrew "Bible" and "Talmud" is the Jewish primary task, raising children, so that he took the right path from childhood, To the old he does not deviate from. "When the age of five to learn" Hebrew Bible ", at the age of ten to learn" Mississauga ", fifteen years old when learning" do not increase knowledge, knowledge will be reduced, do not learn " "Who should be executed [7].

The synagogue became an important place for Jewish religious education. In the synagogue, the congregation received religious education by listening to "Tuo La" and "Talmud", chanting hymns. For the religious function of the synagogue, M. Steinberg said, "The synagogue can be said to be a Jewish school, at least the school's predecessor and foundation." At all levels of school in Israel, studying religious courses is the basic task of every Jewish child.

\section{References}

[1] Dazhou, Zhen Tang, Xu Xiangqun. Chinese people to see Israel [M]. Beijing: Xinhua Publishing House, 1990: 157-158

[2] Huang Ling Yu. Jewish religious customs and external signs [J]. World peoples .2004 (3): 76

[3] Yueqinghua, Ji Fengwen. Jewish folk [M]. Nanjing: Nanjing University Press, 1993: 51-55

[4] Chinese Christian Association. The Bible [M]. Nanjing: Nanjing love India Printing Co., Ltd. 2000

[5] Zhang Qianhong. Dilemma and regeneration: the modernization of Jewish culture [M]. Jiangsu People's Publishing House, 2003.01, 1st edition: 328-329

[6] Fu Youde. Hebrew "Biblical" philosophical thinking [J]. Philosophy Research, 2007 (3): 101

[7] Sainia. Volkswagen Tarim [M]. Yunnan People's Publishing House, 2006.01: 143

[8] Milton • Steinberg. Synopsis [M]. New York: New York Press, 1975: 150. 